\title{
Development Charges in Toronto: Exploring the Disconnect Between Planning Policy and Fiscal Policy
}

\author{
By \\ Angelo Ambrico \\ B.Sc. University of Toronto \\ A Major Research Paper \\ Presented to Ryerson University \\ In partial fulfillment of the requirements for the degree of \\ Master of Planning \\ In \\ Urban Development
}

Toronto, Ontario, Canada, 2018 


\section{Author's Declaration for Electronic Submission of a MRP}

I hereby declare that I am the sole author of this MRP. This is a true copy of the MRP, including any required final revisions.

I authorize Ryerson University to lend this MRP to other intuitions or individuals for the purpose of scholarly research.

I further authorize Ryerson University to reproduce this MRP by photocopying or by other means, in total or in part, at the request of other institutions or individuals for the purpose of scholarly research.

I understand that my MRP may be made electronically available to the public. 


\title{
DEVELOPMENT CHARGES IN TORONTO: EXPLORING THE DISCONNECT BETWEEN PLANNING POLICY AND FISCAL POLICY
}

\author{
Angelo Ambrico, 2018 \\ Master of Planning \\ In \\ Urban Development \\ Ryerson University
}

\begin{abstract}
A development charge is a one-time fee that municipalities in Ontario levy on developers to recover growth related costs associated with new development. In Toronto, development charges have increased rapidly amongst surmounting fiscal pressures for growth related capital infrastructure. Research has found that development charges put an upward pressure on housing prices (Ihlanfeldt \& Shaughnessy, 2004; Ihlanfeldt \& Shaughnessy, 2006; Bryant, 2017), increase the cost of existing housing, (Sishir, 2007) and reduce local economic development activities (Ihlanfeldt \& Shaugnessy, 2004; Jones 2015). This paper argues that future increases to development charge rates in the City of Toronto work counterintuitive to its planning policies. The recommendations provided are based on the idea that municipalities must carefully consider the impacts of high development charges alongside planning policy objectives that they aim to achieve.
\end{abstract}

Key Words: Development Charges, Planning Policy, Fiscal Policy, Housing Affordability 


\section{Acknowledgments}

I would like to thank my supervisor David Amborski for this guidance and support throughout the year. His expertise in the field has provided me with a depth of understanding that has been invaluable.

I would also like to thank my family, friends and colleagues for their support. 


\section{Table of Contents}

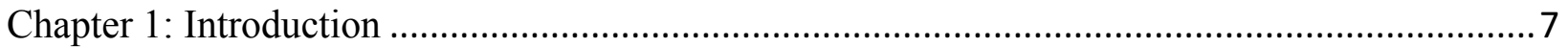

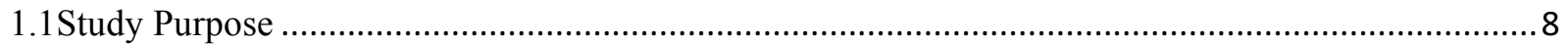

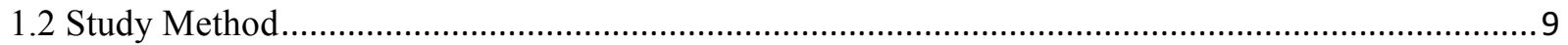

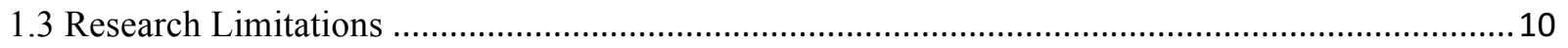

Chapter 2: An Overview of Development Charges in Toronto ..................................................11

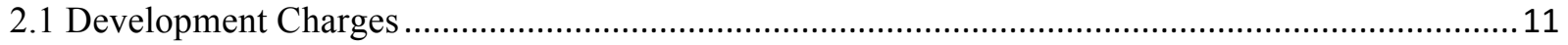

2.2 History of Development Charges in Ontario..........................................................................12

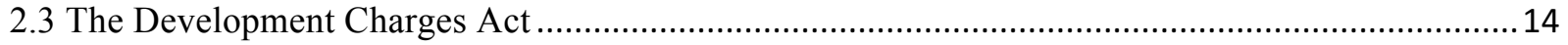

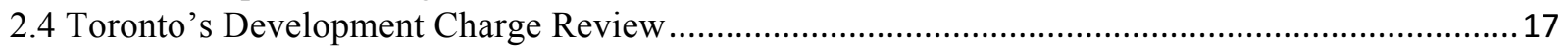

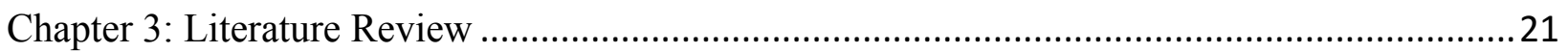

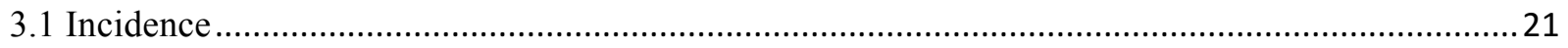

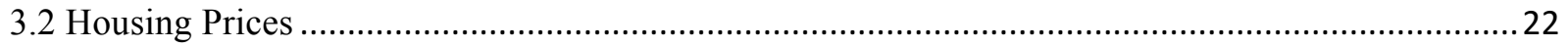

3.3 Efficient Growth Patterns.......................................................................................................... 24

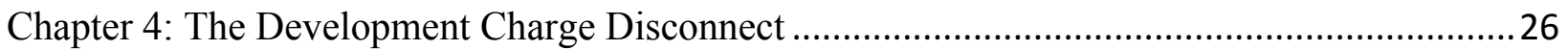

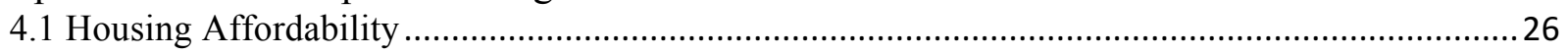

4.1.1 Upward Pressure on Housing Prices............................................................................ 28

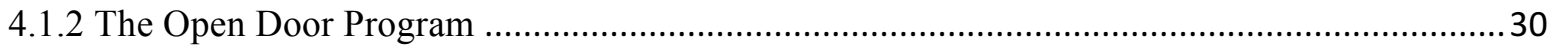

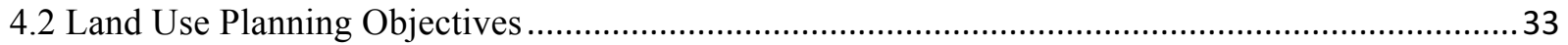

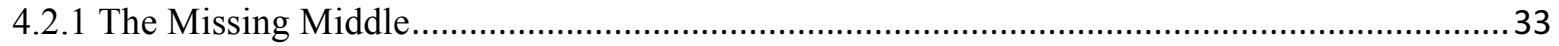

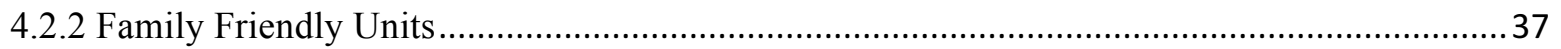

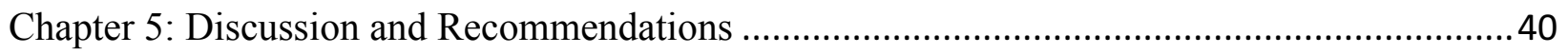

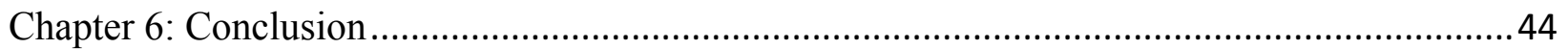

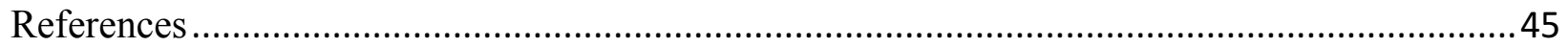

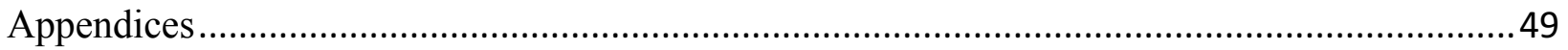

Appendix A: Residential Development Charge Rate, City of Toronto 2018 ……………………........49 


\section{List of Figures}

Figure 1: The Development Charge Study Process in Ontario................................................ 16

Figure 2: Residential Development Charge Allocations ....................................................19

Figure 3: Non-Residential Development Charge Allocations .................................................... 19

Figure 4: Maximum Calculated Development Charge Rates (2009-2018) ................................20

Figure 5: Year over Year Increase in Housing Prices.......................................................... 27

Figure 6: Phased-In Development Charge Rate Increases..................................................... 29

Figure 7: Development Charges for 2 Bedroom Apartments ........Error! Bookmark not defined.

\section{List of Tables}

Table 1: Proposed Rate Increases as per 2018 Background Study .........................................18 


\section{Chapter 1: Introduction}

A development charge is a one-time fee that municipalities in Ontario levy on developers to recover growth related capital costs associated with the infrastructure required to service new developments ${ }^{1}$. These charges are paid by property developers, typically at the time building permits are issued, and must be used to pay for the infrastructure necessitated by the new development. This includes the financing of 'hard' costs, such as roads and sewers, as well as 'soft' costs such a community facilities and neighbourhood parks (Slack, 1994). In Ontario, these charges are determined by a background study, which outlines a municipalities growth forecast, the existence of excess capacity, and future capital expenditures over a ten-year period (Slack, 2002).

While development charges are widely used across the Greater Toronto Area (GTA), municipalities tend to maximize these fees in response to their limited revenue raising capacity. Toronto is in the process of completing its mandatory development charge by-law review and has proposed to increase these charges on average by $98 \%$ across all residential unit types (City of Toronto, 2018). Municipalities must carefully consider the impacts of high development charges alongside the several planning policy objectives that they aim to achieve. There is a large body of academic literature suggesting several negative impacts of development charges related to the incidence of the changes, and its impacts on housing affordability and local economic development. Research has found that development charges put an upward pressure on housing prices (Ihlanfeldt \& Shaughnessy, 2004; Ihlanfeldt \& Shaughnessy, 2006; Bryant, 2017), increase the cost of existing housing, (Sishir, 2007) and reduce local economic development activities (Ihlanfeldt \& Shaugnessy, 2004; Jones 2015).

\footnotetext{
${ }^{1}$ A development charge is often referred to as an 'impact fee' in the United States, or a 'development cost charge' in British Columbia.
} 


\subsection{Study Purpose}

The purpose of this research is to explore the disconnect between planning policy and fiscal policy, specifically in relation to development charges as a financing tool for growth-related capital costs. In doing so, it will be argued that the current rate increase proposed by the City's finance department works counterintuitive to planning policy objectives. Instead of supporting planning objectives the development charge functions to undermine them. As part of this analysis research will be guided by the following questions:

1. What are the potential impacts of increasing development charges in the City of Toronto?

2. How can increasing development charges work as a disincentive to achieving Toronto's planning policy objectives?

3. What are the alternatives to development charges to finance growth related capital costs?

To further explore these issues this paper will first, summarize the current development charge system in Toronto, including the history of the charge, Ontario's current development charge legislation, and the ongoing review process for the City of Toronto 2018 Development Charge By-law. Second, this paper will provide an overview of the academic literature related to the incidence of development charges, its impacts on housing affordability, and how the structure of development charges can align with land-use planning objectives. Third, an outline of key planning policy objectives in the City of Toronto Official Plan will be compared against the potential negative effects of increasing the charge. Finally, a series of policy recommendations related to the alternatives of development charges to finance growth related capital costs will be proposed. 


\subsection{Study Method}

To explore the disconnect between planning policy and fiscal policy in the City of Toronto, a multi-method approach was used. Field research was completed by attending two public consultation sessions on the latest development charge by-law review process. This included note taking at the Mayor of Toronto's Executive Committee where residents, businesses and local Councillors addressed their concerns with the latest Development Charges Background Study and the proposed rate increases ${ }^{2}$. Attending these meetings provided a framework for understanding key planning policy and fiscal policy objectives in the City, and the opportunity to understand significant stakeholder issues related to the review process, calculation methodology, and quantum of the charge.

Second, an extensive policy review was completed on the development charge system in Ontario in order to provide a greater context for the topic. This included a historical analysis to understand the driving forces leading to the creation of Ontario's development charge legislation, as well as a review of the current legislative framework governing development charge applications in the Province. Official Plan policies and secondary studies were also reviewed to understand the City's key planning policy objectives and how these policies related to fiscal policy within the City of Toronto.

To compliment the field research and the policy review, a literature review was conducted to understand the incidence of development charges related to housing affordability and economic competitiveness. To relate these finding to the Toronto context, market research was performed to better understand current housing market dynamics in the City of Toronto. This included

\footnotetext{
${ }^{2}$ The Executive Committee meeting was held on January 24, 2018. Associated summary reports, background information, and stakeholder communications were retrieved from: http://app.toronto.ca/tmmis/viewAgendaItemHistory.do?item=2018.EX30.3
} 
analyzing the latest housing market trend reports released by the Toronto Real Estate Board (TREB), as well as the Canadian Mortgage and Housing Corporation (CMHC).

\subsection{Research Limitations}

This research is limited by data availability and academic literature on development charges in the Canadian urban context. While there is a large body of academic research on impact fees in the American context related to the incidence of the charge and its impacts on housing prices, there is currently no up-to-date research on how much of the charge is incorporated into housing prices in the Toronto context. It is also important to note that while there is a wide variety of literature pertaining to impact fees in the United States, these municipalities have very different institutional arrangements and offer a broader range of financial sources that are currently not available or replicable to Canadian municipalities (Ambroski, 2011). Due to this, a case study analysis comparing different jurisdictions in the American context was not pursued, largely due to the prescriptive nature of the Development Charges Act in Ontario.

Additionally, a majority of development charge research tends to focus on suburban growth patterns and the impact of the charge as it pertains to low density development in greenfield areas. Research on the role of development charges in built up urban areas, where infill redevelopment is most common, is absent from current research. This gap in research provides an opportunity to build on some of the different aspects of the charge in dense urban environments. Due to some of these limitations, this report is intended to act as a discussion piece based on the academic literature related to development charges, data availability from the real estate market, and opinions published in reports by planning consultants and development industry professionals. 


\section{Chapter 2: An Overview of Development Charges in Toronto}

\subsection{Development Charges}

A development charge is a one-time fee that municipalities in Ontario levy on developers to recover growth related capital costs associated with the infrastructure required to service new developments. Over the past fifty years, the use of development charges has become widespread and part of the traditional model of growth for municipalities in Ontario. This can be attributed to two primary reasons: First, the charge itself is often justified on the principle that new growth should pay for new growth, and not be a burden on the existing tax-base (Slack, 2002). Municipalities tend to favour development charge increases due to its low political cost in comparison to raising the property tax. (Amborski, 2011). Due to this, they are often perceived as a hidden tax that homebuyers are often unaware is embedded in their purchase price. Second, development charges approximate a user fee and are considered more efficient and equitable than other alternative forms of taxation (Ihlanfeldt \& Shaughnessy, 2004). The charge is considered efficient, since investment decisions reflect the costs of providing the service, and equitable, based on the benefit principle of just taxation, whereby it is possible to identify the beneficiary of the relevant service provided by the charge (Kitchen, 2003).

While development charges are a legitimate revenue raising tool that municipalities use to finance the costs associated with new growth, the overreliance on these charges and is particularly alarming. These charges have increased rapidly across the Greater Toronto Area (GTA), and typically range from $\$ 26,000$ to $\$ 54,000$ per two-bedroom apartment units, or $\$ 60,000$ to $\$ 80,000$ for a single detached home $e^{3}$. Findings from the Altus Group suggests that between 2009 and 2018, these charges have increased 14.3 per cent annually, while the property

\footnotetext{
${ }^{3}$ Based on Development Charge Rate Schedules comparison of Mississauga, Brampton, Markham and Toronto.
} 
tax has increased 2 per cent annually (Wilkes, 2018). The experience in the City of Toronto has been no different. The City currently has one of the most extensive development charge regimes in North America. It considers 17 eligible services, such as transit, roads, and parks and recreation, that the charge can be collected for. Amidst the latest update to the City's development charge by-law, Toronto is currently proposing to increase its rate to nearly double its current rate for units in new residential developments. This includes rate increases of $104 \%$ for two-bedroom apartment units from $\$ 25,366$ to $\$ 51,740$ per unit, and for single-detached dwellings, an increase of $114 \%$ from $\$ 41,251$ to $\$ 88,391$ per unit (City of Toronto, 2018). This highlights an alarming trend of municipalities increasing development charges to the greatest extent possible in response to increasing fiscal challenges and revenue shortfalls. Municipalities must carefully consider the impacts of high development charges alongside several other policy objectives that they aim to achieve.

\subsection{History of Development Charges in Ontario}

The application of development charges in the Ontario context can be associated with the growing trend of municipalities shifting the responsibility of financing growth-related services for new developments onto the private sector. Rapid urbanization in Toronto during the post-war era created an increased demand for housing, requiring the financing of capital infrastructure service new development. This included hard services such as water, sewers and roads within new growth communities, which were traditionally provided and financed by local governments through increased expenditures and debt financing (Slack and Bird, 1991). In Toronto, these

growth pressures were a contributing factor for the creation of a metropolitan form of government, which in part was a response to increasing fiscal pressures, so that fringe 
developments could take advantage of the City's larger assessment base when issuing debt to provide new infrastructure (Amborski, 1988).

With these growing fiscal pressures and revenue shortfalls, municipalities increasingly sought ways to shift these growth-related costs onto developers. Municipalities soon began to require that developers provide the necessary services internal to newly created subdivisions, known as lot levies during the 1950's and 1960's. These conditions were imposed by creating agreements between municipalities and developers as a permission to develop and build on the land, which would later become known as the subdivision agreement (Amborski, 1988). In addition to providing services internal to these subdivisions, municipalities began to require developers make cash contributions for growth related off-site capital services, such as water trunk lines and plants (Slack and Bird, 1991). By 1959, the legality of the subdivision agreement as a municipal instrument was clarified in the Planning Act, which clearly established that a municipality could make the developer financially responsible for the provision of infrastructure internal to the subdivision (Amborski, 1988). The Municipal Act also stipulated that municipalities must spend the collected contributions on services that benefitted the occupants of the land within the subdivision, a measure attempting to ensure accountability with regard to the ways in which collected monies were to be spent (Amborski, 1988).

By the 1970s, housing construction booms in Ontario meant that municipalities would become increasingly more interested in using lot-levies as a revenue tool. It became common place for developers in Ontario to negotiate with municipalities on a site-specific basis to assess such charges (Tomalty and Skaburskis, 2003). These site-specific arrangements were seen largely as inadequate from a municipal perspective, as they were often unpredictable due to uncontrollable variables such as the sophistication of developers involved. Larger and more 
experienced developers were often able to reduce their contribution for growth related infrastructure, by either influencing municipal councils or arguing before the Ontario Municipal Board (OMB) (Tomalty and Skaburskis, 2003). Disagreement amongst municipalities and developers, which were often challenged judicially at the OMB, rested largely upon central issues related to what 'hard' and 'soft' services should be included in the charge, and whether all growth-related services should be part of the calculation (Amborski, 1988).

Amongst the unpredictability and variation in what charges were to be included in the development charge, and the threat of dispute through OMB mechanisms, municipalities were often forced to cover the costs associated with growth, threatening some with bankruptcy (Tomalty and Skaburskis, 2003). To address this financial risk of site-specific negotiations, municipalities began to adopt fee schedules not based on site specific considerations, but rather on average cost pricing per capita of unit dwelling. Municipalities began to calculate a municipal-wide cost schedule, based on either historical average cost for a typical subdivision, or through an estimate of the capital costs due to an expected increase in population (Amborski, 1988).

\subsection{The Development Charges Act}

In response to the financial risks municipalities were faced with in relation to financing growth-related capital infrastructure, and the unpredictability of the site-specific negotiating system, the Association of Municipalities (AMO) began lobbying for change. This included legislative changes for a municipal-wide development charge by-law to replace the site-specific approach (Amborski, 1988). In response, the Province enacted the Development Charges Act (DCA) in 1989, which strongly favoured the municipal position and gave authority for 
municipalities to pass by-laws imposing charges on new developments to recover the capital costs associated with servicing new developments. The $D C A$ clearly established legal authority for municipalities to levy development charges, while permitting them to levy charges against both 'hard' and 'soft' infrastructure, as well as extend the power to levy charges to school boards (Tomalty and Skaburskis, 2003). This meant that the power to levy a development charge on any one developer was extended to include four bodies: the regional municipality, the local municipality, the public-school board, and the separate school board (Slack and Bird, 1991).

Today, the $D C A$ is a highly prescriptive piece of legislation, enabling municipalities in Ontario to recover growth related capital costs necessitated by new development. The $D C A$ establishes what types of services are eligible for cost recovery by development charges as well as the method of calculation to determine the charge. In order to determine a development charge fee by-law, the Act stipulates the municipality must perform a background study which provides a detailed overview of the expected growth within a municipality, the services required to meet the demands of such growth, and a detailed account of the capital costs necessary to support anticipated growth. Figure 1 summarizes the specific study process that must be followed by a municipality in the determination of development charges. 
Figure 1: The Development Charge Study Process in Ontario (Source: Hemson Consulting, 2018)

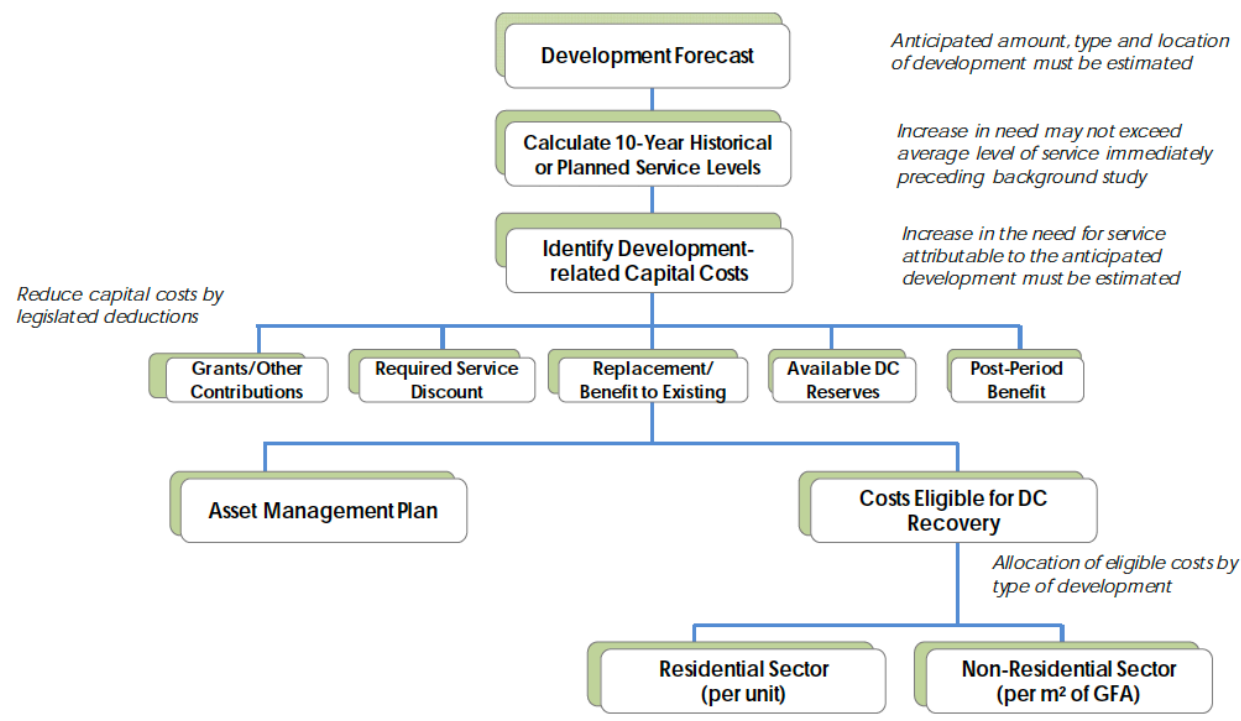

Recent amendments to the DCA through Bill 73: Smart Growth for our Communities Act, 2015, which came into effect on January 1, 2016, has made further changes that aim to make the development charge system more predictable, transparent and accountable (Ministry of Municipal Affairs and Housing, 2016). Notable changes include the requirement that municipalities must 'consider' using an area-based rating to reflect cost differentials of servicing new developments as part of their development charge background study. Additionally, increased reporting requirements now require that the treasurer of a municipality provide a financial statement to Council and the public related to opening and closing balances, and transactions related to DC reserve funds in a given municipality. These statements must also identify assets whose capital costs were funded under the development charge by-law, and the manner in which any portion of capital costs not funded under the development charge by-law will be funded (Wood Bull, 2016). 
Perhaps most notable, Bill 73 changes have significantly increased the amount of capital costs municipalities are able to recover from development charges for new transit initiatives. Changes include the addition of transit from the list of services that are exempt from $10 \%$ capital cost reduction. Additionally, these changes have removed the level of service requirements which based transit level services according to the historic 10-year average. Alternatively, municipalities are now permitted to estimate the increased need for transit services according to a 10-year forward looking level of service, referred to as the "planned level of service".

\subsection{Toronto's Development Charge Review}

Following the recent Bill 73 amendments to the $D C A$, the City of Toronto is currently in the process of updating its development charge by-law. As per the DCA, municipalities are required to review and renew their development charge by-law every five years. As part of the 2018 review process, the City of Toronto is proposing significant increases to the development charges rate collected for residential development projects. This includes an average rate change of $98 \%$ across all unit types for residential developments. The most notable of the proposed changes include 104 per cent increase for two bedroom apartments, a 114 per cent increase for single and semi-detached units, and a 91 per cent increase for one bedroom and bachelor apartments. Proposed rate increases as per the development charge background study are summarized in Table 1. The proposed rate increases are currently in the public consultation phases, and is expected to be considered before Council in March 2018. 
Table 1: Proposed Rate Increases as per 2018 Background Study

\begin{tabular}{|c|c|c|c|c|}
\hline Development Type & $\begin{array}{c}\text { Current Rate } \\
\text { (Effective Feb } \\
1,2018 \text { ) }\end{array}$ & $\begin{array}{l}2018 \text { DC Study Calculated } \\
\text { Maximum Rates }\end{array}$ & $\begin{array}{c}\text { Change from } \\
\text { Current Rates } \\
\text { (\$ Value) }\end{array}$ & $\begin{array}{c}\text { Change from } \\
\text { Current Rates } \\
(\%)\end{array}$ \\
\hline \multicolumn{5}{|c|}{ Residential (\$ per unit) } \\
\hline Dwelling Room & $\$ 11,028$ & $\$ 23,954$ & $\$ 12,926$ & $117 \%$ \\
\hline $\begin{array}{c}\text { Apartments (Bachelor \& } \\
1 \text { Bedroom) }\end{array}$ & $\$ 17,644$ & $\$ 33,775$ & $\$ 16,131$ & $91 \%$ \\
\hline $\begin{array}{l}\text { Apartments }(2+ \\
\text { Bedroom })\end{array}$ & $\$ 25,366$ & $\$ 51,740$ & $\$ 26,374$ & $104 \%$ \\
\hline $\begin{array}{c}\text { Multiples (Bachelor \& } 1 \\
\text { Bedroom) }\end{array}$ & $\$ 24,816$ & $\$ 36,650$ & $\$ 11,834$ & $48 \%$ \\
\hline Multiples (2+ Bedroom) & $\$ 34,742$ & $\$ 73,058$ & $\$ 38,316$ & $110 \%$ \\
\hline Singles \& Semis & $\$ 41,251$ & $\$ 88,391$ & $\$ 47,140$ & $114 \%$ \\
\hline \multicolumn{5}{|c|}{ Non-Residential ( $\$$ per square metre) } \\
\hline Non-Industrial & $\$ 213.65$ & $\$ 449.04$ & $\$ 235.39$ & $110 \%$ \\
\hline Industrial (Calculated) ${ }^{* *}$ & $\$ 213.65$ & $\$ 190.89$ & $\$-22.76$ & $-11 \%$ \\
\hline
\end{tabular}

The City's finance department attributes the increased development charge rates to a number of factors including increases to growth related capital expenditures, as well as higher land and construction costs. But most notably, the increases to the recoverable expenditure levels for planned transit, as well as the elimination of the statutory $10 \%$ discount for transit is the highest contributor to the proposed rate increase (City of Toronto, 2017). As part of the calculation, the city collects development charges for 17 eligible services ${ }^{4}$, however, $73 \%$ for residential and $92 \%$ of non-residential rates are attributed towards three primary services, being transit, roads, water and waste water infrastructure. Figure 2 and Figure 3 summarizes the

\footnotetext{
${ }^{4}$ See Appendix A for eligible services
} 
breakdown of key services collected by the charge. An overwhelming percentage of this charge is attributed to funding transit. In residential projects, $35 \%$ of the charge is allocated to transit, while in non-residential projects $44 \%$ is allocated to transit.

Figure 2: Residential Development Charge Allocations

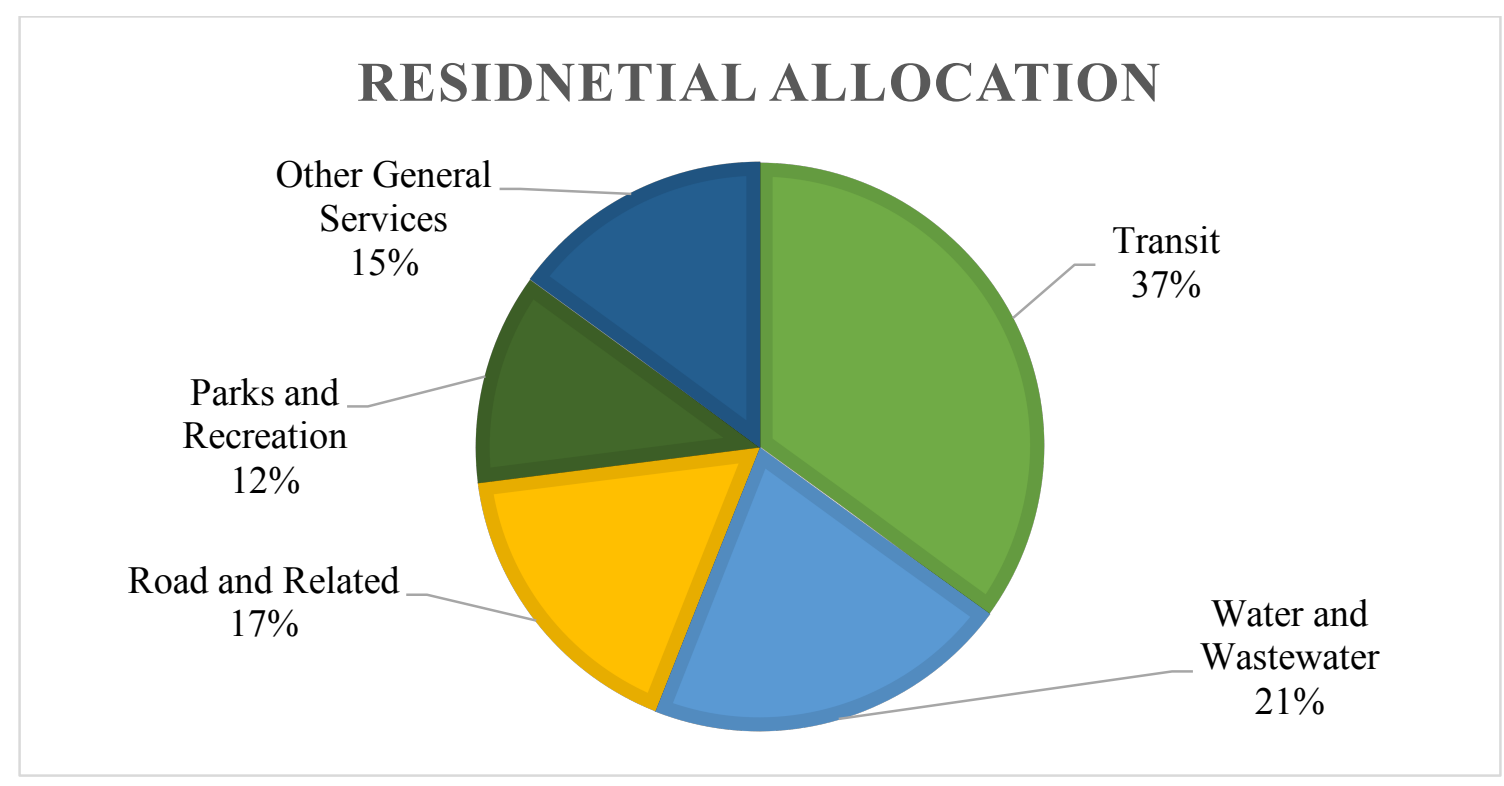

Figure 3: Non-Residential Development Charge Allocations

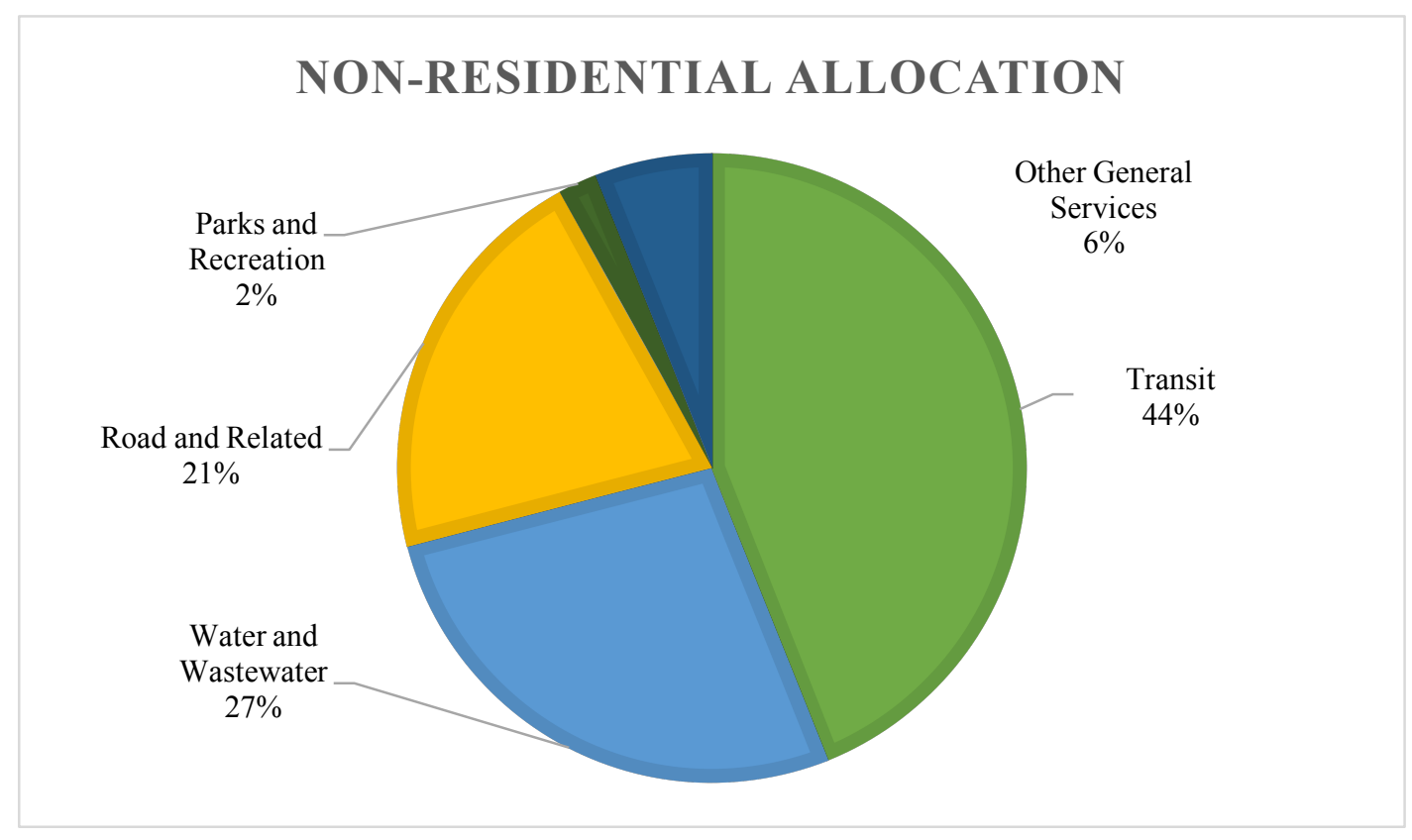


In comparison to other municipalities in the Greater Toronto Area, Toronto has historically had lower development charges than its suburban neighbours. Toronto's current development charge by-law is roughly $30 \%$ below average of neighbouring municipalities such Vaughan and Mississauga (City of Toronto, 2017). This can be attributed to the fact that Toronto already has existing infrastructure in place to accommodate new development, and development patterns are mostly in the form of infill intensification (Amborski, 2011). Additionally, a majority of high-rise developments can typically be associated with lower servicing costs in comparison to greenfield sites which require new water mains, sewers and roads. However, as mentioned above, recent amendments to the DCA have significantly increased the amount of capital costs a municipality can collect for transit initiatives. This is largely reflected in the current rate, as transit makes up nearly half of the proposed rate increases. The latest rate increase comes to light after Toronto recently doubled their development charges in both review periods in 2009 and 2013. Figure 4 shows the maximum calculated development charge rate as per the last two by-laws.

Figure 4: Maximum Calculated Development Charge Rates (2009-2018)

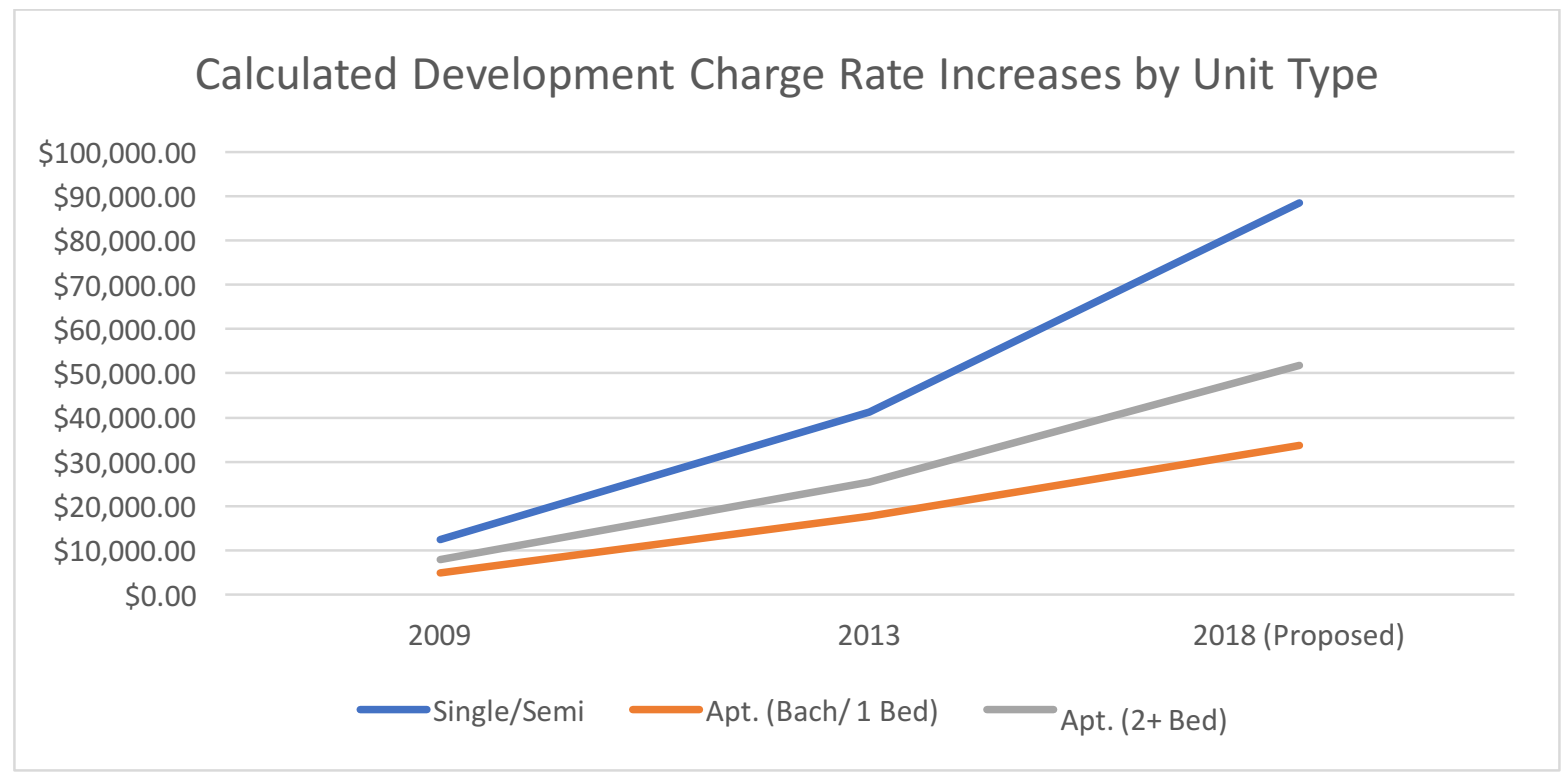




\section{Chapter 3: Literature Review}

\subsection{Incidence}

When a development charge is imposed on a new development, its incidence - the question of who ultimately bears the burden of the charge - is complex and depends primarily on supply and demand factors of local housing market characteristics (Kitchen, 2003). While the development charge is paid by the developer or builder, economic theory has proven that a majority of this charge is passed down to the final end user, either in the form of higher housing prices or commercial rents. However, the incidence of the charge is far more complex and rests on almost every actor at some stage in the development process.

Research by Ihlanfeldt \& Shaughnessy (2004) point out that there are two competing views regarding the incidence of the charge based on theoretical literature. The 'Old View', considers the system of development charges as an excise tax on development. As such, the indirect tax can lead to a range of different outcomes. In the short-term, the 'Old View' predicts that homebuyers and developers will share the burden of the fee in the form of both higher housing prices and lower developer profits. In the long-term, this will reduce the quantity of new homes being constructed, increasing the demand for older housing, thereby raising the price of both new and existing homes. In order to return profits to a normal level, developers will also begin to pay less for developable land, and shift this burden backwards on existing land owners.

Huffman et al., (1998) argues that shifting the burden backwards on landowners is unlikely, due largely to the fact that landowners often have a reservation price below which they will not sell. Conclusions from their research indicate that there is considerable information signaling that the final end user of the property - the occupant - pays a majority of these fees. The authors 
suggest that in the long-term, if developers are unlikely to absorb these fees and they are unable to pass these costs forwards or backwards, they will exit the market.

The assumptions of the 'New View' is based on research from Yinger (1998), which broadens the model to consider the benefits of additional infrastructure (Adams, 2015). Under the 'New View', Ihlandfeldt \& Shaugnessy (2004) suggest that when home prices increase by more than the fee, this indicates that homebuyers recognize the value of the services being provided, and are capitalizing the reduction of future taxes into home prices. Therefore, if the increase in price results from the capitalization of benefits equals the fee, then neither the developer nor landowner bear any burden of the fee. The fee is borne by in the homeowner in the form of higher housing prices, but net of the benefits received from the fee-financed infrastructure there is no burden. However, if these benefits are valued less by the new homebuyer, resulting in an increase in home prices that is less than the fee, then in order to restore developer profits, the price of land declines.

\subsection{Housing Prices}

Theoretical findings regarding the incidence of development charges suggests that these fees result in higher housing prices regardless of the possible actors the burden may be shifted upon. There has been a large volume of literature written in both the American and International context that attempts to quantify the amount of the charge increasing housing prices and issues of housing affordability. Research conducted in the American context by Ihlanfeldt and Shaughnessy (2006) found that impact fees increase the price of new residential development in order to cover the amount of impact fees paid by the developer. In this example, developers appeared to be fully compensated for the impact fee through the increased rate they are able to 
charge for new homes constructed. As a result, the researchers found that an additional $\$ 1.00$ of fees, increases the price of both new housing by roughly $\$ 1.60$. Similarly, findings from Australia support the proposition that infrastructure charges are passed down to home buyers, significantly increasing the cost of new housing. Findings in Brisbane, Australia have indicated that infrastructure charges are a significant contributor to increasing housing pricing and reduced housing affordability. Researchers found that a charge of $\$ 28,000$ levied on the developers of new housing resulted in an additional $\$ 939$ per month in mortgage payments for all housing buyers (Bryant, 2017).

While development charges are typically levied on new developments, they also tend to increase the cost of existing housing as well. This occurs when the price for newly constructed houses rises and increases the demand for older cheaper houses, thereby increasing the selling price as well (Kitchen, 2003). Research conducted in Washington State by Sishir (2007) found that impact fees significantly increases the price of existing homes, roughly by about 83 percent of the amount of the fee. Findings from this research have several policy implications on the inflationary effect of impact fees, particularly on the price of high-quality housing. Researchers predict that these increases will have a worsening effect on affordable housing, especially for households with more than moderate incomes.

Another instance of how impact fees can negatively impact housing affordability is rooted in how the charge is calculated, which can often affect the smallest and most affordable units in a new residential development. Conceptually, if a development charge fee is based upon unit type, for example a single-detached dwelling, and no consideration is given to the actual size of that detached dwelling, this will result in the fixed fee being proportionately higher on the smaller home with a lower value, than on the larger home with a higher value (Nelson et al., 2008). 
Therefore, if the development charge is sensitive to affordable housing, scaling them based on the housing size would solve equity issues related to overcharging smaller houses, which are often worth less than larger houses.

\subsection{Efficient Growth Patterns}

A growing body of research within the literature is how development charges can be used as a tool to encourage land use planning objectives such as intensification and compact built form. Research in the Ontario context suggests that most municipalities do not structure development charges to achieve these goals. Instead, municipalities often adopt an average cost approach, whereby all costs are assigned on a municipal-wide basis based on a certain criteria, such as a detached dwelling unit, so that all projects that meet this criteria, pay the exact same charge regardless of the actual costs they create (Tomalty and Skaburskis, 2003). Cost variations are ignored from the charge, as it does not consider areas that are potentially more expensive to provide a given service. Alternatively, a marginal cost approach would ensure a level of economic efficiency through adopting an area-rating approach that averages costs over a much smaller area. An area specific rating levies different costs to different areas, depending on the approximated cost of delivering services to that area (Tomalty and Skaburskis, 2003). A marginal cost method can therefore be seen as economically efficient since it considers the full cost of delivering the service and potential cost variations.

Despite the economic efficiency of using a marginal cost approach, the majority of municipalities in the GTA remain using an average cost approach to finance growth related capital costs. This has many implications in terms of how new residential growth occurs in the GTA, as many argue that the calculation is disconnected from planning policy objectives. The 
most prevalent argument against the so-called mispricing of development charges is that it is largely seen as encouraging urban sprawl. Slack (2002) argues that when a uniform charge is levied across the entire municipality that does not include variations of the actual cost of providing these services, it promotes inefficient development patterns. In turn, this results in underpricing hard services in low-density neighbourhoods, and overpricing high-density neighbourhoods. Therefore, a development charge that is the same amount per unit, regardless of where it is located does not reflect the municipality's true cost, and thus does not lead to efficient development decisions (Slack, 2002).

Research by Blais (2010), suggests that the mispricing of the development charge structure leads to a perverse subsidy resulting in financial incentives for inefficient development. They suggest that when prices are based on average costs, rather than marginal costs, properties which incur lower-than-average costs (such as an infill development project) pay more for their costs, while those properties than incur higher-than-average costs (such as a greenfield development), pay less for their costs. As a result, this is largely seen as encouraging sprawl through a hidden cross subsidy. Blais goes on further to note that development charges as currently structured is a deeply flawed tool with respect to development patterns, as it encourages expensive development patterns by raising the cost of servicing them. Instead of supporting planning objectives related to compact growth and efficient development patterns, the development charge functions to undermine them. 


\section{Chapter 4: The Development Charge Disconnect}

The following section will provide an overview of the findings. It will be shown that fiscal policy has tended to work counterintuitive to planning policies, particularly in regard to housing affordability and desired growth patterns.

\subsection{Housing Affordability}

Perhaps the most controversial issue surrounding development charges in the academic literature is how these charges impact housing affordability. In Toronto, this remains an important topic of discussion, particularly in light of current housing market characteristics. Findings from the 2016 Census have indicated that Toronto has now outpaced Vancouver as the least affordable city in Canada. Among census metropolitan areas in 2016, 33.4\% of households in Toronto paid more than $30 \%$ of their income on shelter costs. In comparison, $32 \%$ of households paid more than 30\% in Vancouver (Statistics Canada, 2017). In Toronto, recent data trends from the MLS Price Index Report published by the Toronto Real Estate Board (TREB) has reaffirmed these findings as seen in the substantial growth price growth of both detached housing, and more recently condominium home prices as shown in Figure 4. The latest housing market report published in January 2018 has indicated an average sale price for a detached home in Toronto being $\$ 1,080,800$. This is slightly lower than its peak in July 2017 , where average detached homes in the city were selling for $\$ 1,146,100$. Based on the data, it would appear that this has resulted in an upward pressure on condominium home prices in Toronto. Between January 2017 and January 2018, the average price of a condominium rose 15\%, to its latest average sale price of $\$ 492,900$. 
Figure 5: Year over Year Increase in Housing Prices (Source: TREB)

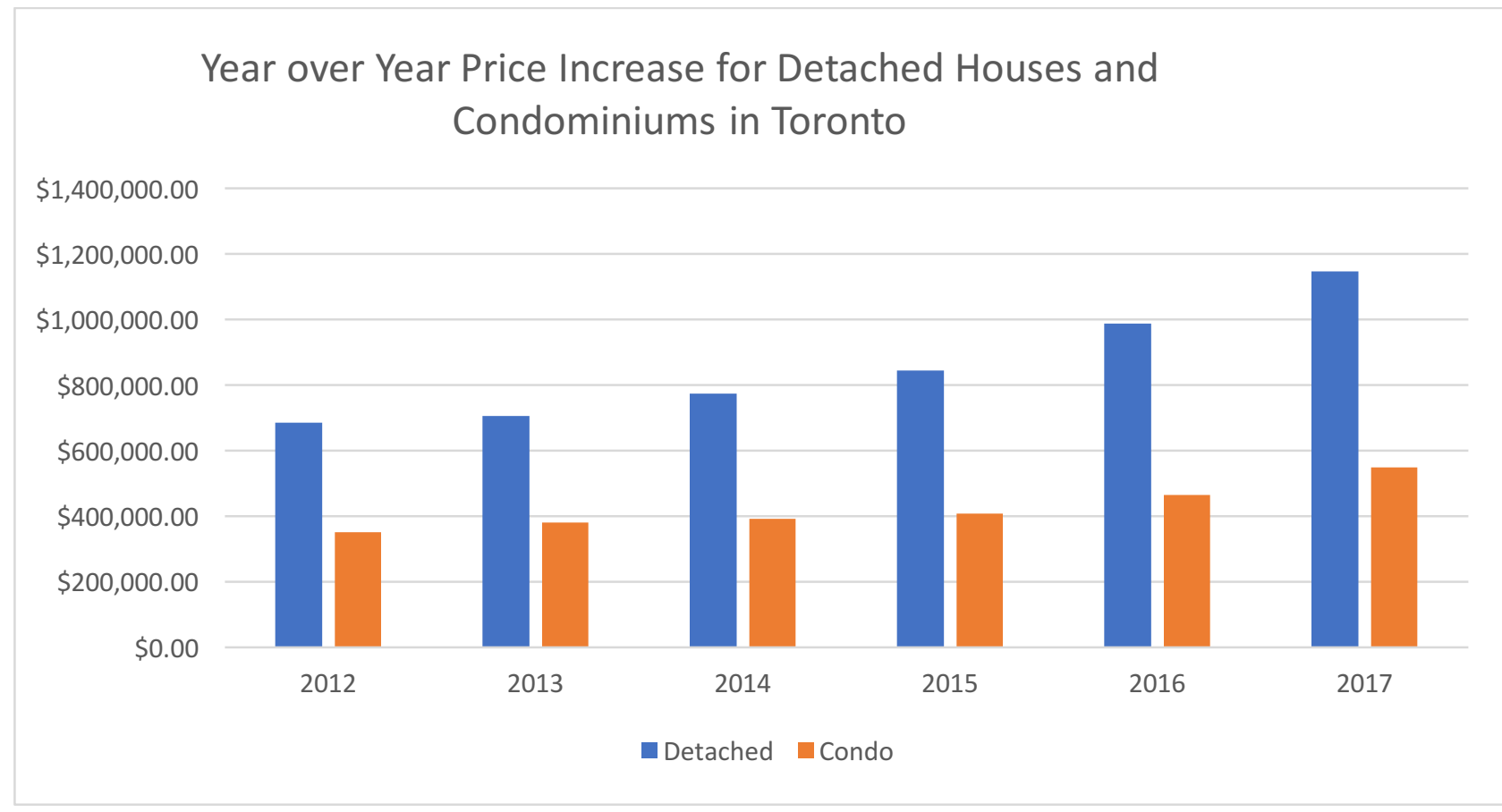

Understanding rapid year-over-year price gains in residential real estate values is complex and dependent on a number of factors. A recent report published by the Centre for Urban Research and Land Development attributes this issue to land use policy that has constrained land supply for new ground-related housing. Amborski and Clayton (2017) argue that the shortfall of serviced sites for the construction of ground-related housing, where the demand is high, is currently not being met. This in turn is creating a mismatch in housing between the type of units being brought to the market, and the type of housing that is in demand, and can be largely seen as one of the causes of rapid year-over-year housing price increases. The issue of housing affordability has also garnered significant media attention which has also prompted a number of political responses, as seen in high profile announcements such as Ontario's Fair Housing Plan. These policies were first introduced in 2016, which sought to remove speculation from the housing market by introducing measures such as a foreign buyers 
tax, vacant homes tax and rent control (Ministry of Municipal Affairs and Housing, 2018). The Plan also considers ways to increase housing supply, such as activating the Province's surplus lands for new housing, and finding ways to expedite the development approvals process.

\subsubsection{Upward Pressure on Housing Prices}

While there is a complex set of supply and demand market characteristics which can be attributed to the rise in housing prices, what is alarmingly absent from policy discussions is the impact of development charges placing an upward pressure on housing prices. Development charges have increased disproportionately in comparison to other municipal own-source revenues such as property taxes. Recent findings from the Altus Group have indicated that in Toronto, between 2009 and 2016, property taxes have increased 2 per cent on average annually. In comparison, between 2009 and 2018, development charges have increased 14.3 per cent on average annually (Wilkes, 2018). As mentioned in the previous section, the past three development charge by-law review processes resulted in the significant increase of development charges. Figure 6 shows the increase of development charges over the past three development charge by-laws for apartment units. After the initial two-year freeze on development charges between 2009 and 2011, rate increases were phased-in twice a year by roughly 5 to 25 per cent depending on housing starts (Amborski, 2011). These charges are often accompanied by other growth-related charges such as Section 37, Height and Density Bonusing, and Section 42, Parkland Dedication, adding further to the fees collected for growth related costs. 
Figure 6: Phased-In Development Charge Rate Increases

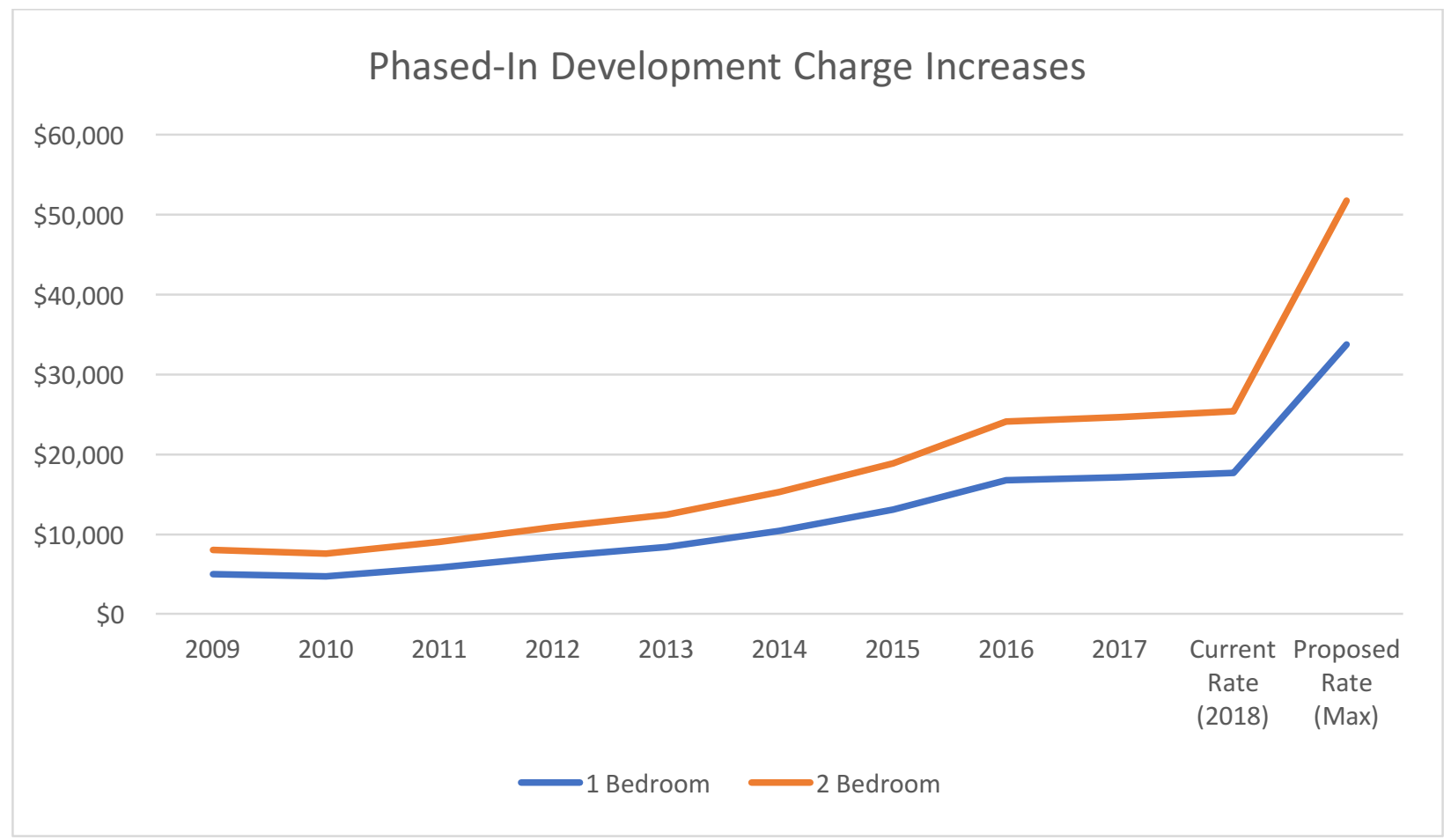

Housing affordability is a large component of Toronto's Official Plan. The overarching policy goal is to ensure that adequate and affordable housing is maintained in the City, due to benefits such as quality of life, economic competitiveness, and social cohesion. As part of Section 3.2.1 of the Official Plan, a clear intent of Housing policies is to provide a full range of housing, in terms of form, tenure and affordability across the City. Careful consideration must be given towards raising development charges in achieving these policy objectives. This also raises the questions regarding how development charges have contributed to increased housing prices and the types of housing being developed.

Academic literature on development charges supports the notion that these fees result in higher housing prices. While difficult to quantify exactly how much of this charge is borne by different actors throughout the development process, in a 2008 report titled Over the Top, BILD estimates that the impact of development charges on new homeowners is drastic. Based on 
findings from over a decade ago, approximately $\$ 30,000$ of the charge is incorporated into price of an average new home (BILD, 2008). After including the total amount of government imposed fees (such as land dedications, taxes, building permits, and processing fees), government-driven costs can represent roughly $20 \%$ of the average house price. It is important to note that this report was published prior to the past two development charge rate increases. Any increases to development charge rates will likely result in higher building costs for developers, which can be attributed to government imposed growth related fees.

The proposed 2018 City of Toronto development charge by-law can largely be seen as an exercise of what the 'market will bear' approach. This is particularly evident in the financial analysis regarding the potential housing market impacts of higher fees. The Background Study suggests that a majority of the development charges will be borne by the owners of developable land (Hemson, 2018). As such, higher development charges are justified by tangible savings in the property taxes, although developers may compensate for this by increased home prices, or rental prices, by a small magnitude. This is a particularly dangerous assumption in light of current housing market characteristics. Municipal staff must carefully consider the impact of high development charges in the context of an already unaffordable housing market. The current rate increases have little consideration for maintaining the overall housing affordability goals of the Official Plan, and can be seen as a disconnect away from its housing policies.

\subsubsection{The Open Door Program}

Despite what some of the findings suggested above, there is widespread recognition from policy makers that there must be financial incentives for the development of affordable housing. The Open Door Affordable Housing Program was approved by Council in 2016 with the intention of accelerating affordable housing construction by providing financial contributions 
from the city, fast-tracking planning approvals and activating surplus public lands (City of Toronto, 2017). Amongst the financial incentive component under this program, the City is prepared to provide exceptions from fees such as planning application fees, development charges, building permit fees, and residential property taxes.

The City defines affordable housing within the program as any "new housing where the total monthly shelter is below Toronto's average market rent (AMR) by unit type as reported in the fall of each year by CMHC." (City of Toronto, 2017). Only eligible projects that meet this criterion may be considered for the Open Door Program. This includes new construction of affordable rental housing units, the acquisition and rehabilitation of existing affordable rental housing buildings, and social housing projects. There are several components within this application for developers to qualify for the program. Since its adoption, there have several developments that have come on stream, which have increased the number of affordable housing projects proposed in Toronto. Development charge relief in this case, can be seen as a fiscal policy which works to encourage Official Plan policies related to building more affordable housing options in the City.

While the Open Door Program establishes a mechanism for development charge relief for affordable housing projects, it does not necessarily provide affordable solutions to those, that by definition, do not qualify for the Open Door Program. A central component of this is the requirement that housing must be in the form of rental tenure and not homeownership. This has important implications towards the goal of creating a complete housing system. For example, not-for-profit housing providers such as Habitat for Humanity works towards building homes for families through an affordable homeownership model. They mostly operate as a charity and obtain a major source of their funding from private donations. As part of this model, Habitat 
partners with families to assist them in paying an interest-free mortgage geared towards their income (Habitat for Humanity, 2018). This creative affordable homeownership model bridges the gap for low-income working families by providing them the opportunity to build and own their own home.

By definition, this form of affordable housing does not fit into the current Open Door Program eligibility requirement due to the homeownership tenure. Instead, applicants must construct affordable rental housing to be eligible. This works counter to a 'Housing First' approach. It provides no financial incentives for other organizations that are an important requirement towards building a healthy housing system. Habitat for Humanity suggests that on average 23 per cent of the costs to build affordable ownership homes is allocated towards government fees and taxes, including development charges ${ }^{5}$. Habitat for Humanity suggests that of the 200 homes in their development pipeline, a cost of $\$ 5.3$ million will be paid to the city, as per the current development charge by-law. In the event that the City approves the proposed 2018 development charge by-law, this cost will increase to $\$ 10.5$ million (City of Toronto, 2018). Habitat argues that this will have a significant impact on their business model. At these rates, for every six habitat homes built the total fees will equate to the cost of a seventh home. Therefore, an increase in development charges will have detrimental impacts on the capacity for not-for-profit organizations to provide more affordable housing.

\footnotetext{
${ }^{5}$ This percentage was suggested during the Executive Committee meeting held on January 28, 2018
} 


\subsection{Land Use Planning Objectives}

There are also a number of broader land use policy considerations that must be considered in the design of development charges. The following section will discuss the impacts higher development charges may have on the City's desirable growth outcomes. This will include how development charges may impact the so-called 'missing middle' along Toronto's designated Avenues, and the feasibility of family friendly units in new developments.

\subsubsection{The Missing Middle}

An important land use policy objective identified in the City of Toronto Official Plan is to encourage new mid-rise developments along the City's designated Avenues. Mid-rise buildings range from five to eleven stories and are considered well suited for arterial roads because they are more human-scaled in terms of size and their built form can fit into existing neighbourhoods. Encouraging new mid-rise buildings also support a number of planning policy goals, as they can create pedestrian friendly environments, can make better use of existing public transit infrastructure, and distribute density evenly across the City (Canadian Urban Institute, 2009). It is often argued that constructing more mid-rise development in Toronto can also help provide alternative housing solutions for households, which may potentially help solve housing affordability issues, by increase the diversity in housing stock. For over a decade this building typology has been the preferred form of gentle density to achieve Toronto's intensification goals.

While planning discourse identifies this building typology as highly desirable, it has more recently become known as the 'missing middle', because there have been so few successful midrise developments constructed in Toronto. A recent report published by the Canadian Centre for Economic Analysis argues that the need for more mid-rise development, is a key component to 
increasing housing affordability in the City of Toronto. Findings indicate that roughly 45 per cent of people live in detached housing, while 35 per cent live in apartment housing. This leaves only 20 per cent of housing dedicated to the 'missing middle' (Canadian Centre for Economic Analysis, 2017). This report argues that increasing the productivity of existing land with higher densities will allow for the provision of additional housing, while better utilizing existing infrastructure, especially in areas along major transit lines. While there a number of desirable planning outcomes associated with mid-rise developments, there are a number of barriers preventing the construction of mid-rise buildings in Toronto. It is generally argued that there are three primary obstacles: economic feasibility, planning policy, and technical requirements.

Developers often argue that there are too many City imposed obstacles for mid-rise developments which threaten the fragile economics of mid-rise buildings (Dalglish, 2017). Some developers have cited that the Mid-rise Buildings Performance Standards lack flexibility and thereby constrain the viability of these projects. Often, these guidelines are treated by planning staff as strict rules making it more difficult to build these projects leading to lengthy planning delays (Dalglish, 2017). Members from BILD also argue that the City has not taken the necessary steps to encourage mid-rise developments. Zoning by-laws have not been updated to pre-zone the Avenues in order to support this type of development (BILD, 2017). A report published by the Canadian Urban Institute found that 75 per cent of mid-rise projects required a zoning by-law or official plan amendment (Canadian Urban Institute, 2009). Therefore, the development process and policy barriers have added time and money to mid-rise projects. This has threatened the economics of mid-rise buildings as developers often feel as though they are not worth the trouble, especially since they typically have much lower returns then a high rise project. 
It is generally argued that there a number of rules and incentives that tilt the playing field against mid-rise projects. There are a number of additional cost considerations which generally make mid-rise developments not economically feasible. In general, the fixed-costs of a mid-rise project (including design, approvals and mechanical systems) are much higher for midrise projects in comparison to high-rise. In high-rise developments, these costs can be spread over the expense of several hundred units. In a mid-rise project, these costs can only be spread across 100 units or less (Dalglish, 2017). Overall, the risks and costs remain too great for midrise developments and provide no real advantage for developers in comparison to high-rise projects. While the total return on these investments are much lower, developers often choose to construct more financially attractive options (Canadian Urban Institute, 2009).

Considering the economic challenges of making mid-rise work in Toronto, increasing development charges to nearly double the current rate is likely to have a significant impact to the financial viability of future mid-rise projects. Toronto's former Chief Planner, Jennifer Keesmaat, a major proponent of mid-rise buildings along Toronto's Avenues, suggests that the latest proposed development charge increase will have a profound impact on the construction of mid-rise developments, especially in suburban locations (Keesmat \& Galloway, 2018). In an interview with the $\mathrm{CBC}$ in light of Toronto's development charge by-law review process, Keesmaat argues that the biggest concern for the City of Toronto is the divide of new growth. New development tends to be concentrated in the downtown core, while there has been a much slower pace of growth in the inner suburbs. Despite this, there has been a surge in public investment in suburban areas of Toronto, primarily in the form of new public transportation projects, such as the Spadina Subway extension and Eglinton Crosstown. The success of these 
projects must be accompanied by intensification and increased residential developments to support ridership and create complete communities where these investments have taken place.

The biggest obstacle to achieving this is whether mid-rise development projects will be able to absorb these additional costs. Keesmaat thinks that this fee will be a great disincentive where land values are lower. In urban areas, where land values are higher, developers have been able to absorb higher development charges, by charging more for each residential unit. This is unlikely in suburban locations, as the pro forma often does not work to make these projects viable. Even Toronto's Development Background Study acknowledges this. The Background study states that in poor housing markets, house prices may be unable to absorb development charge increase, which in turn may impact profits and/or construction activity (p.53). But argue that in high growth areas often impose higher development charges to maintain high service levels. Keesmaat concludes that this is a tipping point for the success of these types of projects. She suggests a good way to approach this issue it to have a pricing model ${ }^{6}$. A pricing model can consider the spatial implications of Toronto's growth patterns and can contribute towards the City's desired growth outcomes.

The proposed increase to Toronto's development charges works counterintuitive to planning policy objectives that incentivize mid-rise development projects along the City's Avenues. Recognizing that development charges can be seen as a large deterrent to the construction of mid-rise development projects, findings from a survey conducted by Canadian Urban Institute suggested that differential fee system developments may help better encourage mid-rise developments. One suggestion included that DC's be staggered throughout the development process to better encourage the development of mid-rise buildings or decreased

\footnotetext{
${ }^{6}$ This interview was recorded on Metro Morning on January 23, 2018 at this link: http://www.cbc.ca/player/play/1143452739745
} 
(Canadian Urban Institute, 2009). Should the City of Toronto follow through with their proposed increases, developers will have to find other ways to make these projects financially viable, or otherwise, will likely not construct them in areas where the City has planned for.

\subsubsection{Family Friendly Units}

A clear policy direction of Toronto's Official Plan is to create "an attractive, safe, and healthy city where children are valued and residents have access to housing, support services and recreational activities" (City of Toronto, 2016). As part of this policy objective, planning staff addressed the issue of encouraging more family friendly units in new high-rise developments through the Growing Up Study. A key finding from this study was that there was a significant gap between the type of units currently being constructed, and the demand for units that may be required in the future. In order to ensure that units in new vertical neighbourhoods can better accommodate households with children, the City has developed a set of draft guidelines to encourage more diverse housing options. A key intent of these guidelines is to require new buildings to have a minimum of $25 \%$ large units in new buildings that contain more than 20 units (City of Toronto, 2017).

There are several planning policy objectives that can be satisfied by ensuring larger units in new development projects. Larger residential units may not only accommodate households with children, but also households with different family compositions, including seniors with home care. In doing so, this can also expand the current housing stock providing a greater array of unit sizes in the downtown core. However, developers are often unfavourable to constructing larger units for a number of reasons. It has been noted that larger units, such as three bedrooms are the last units to sell in new developments. Members from the development community contend that this is because they are more expensive to buy and are associated with higher 
carrying costs, such as maintenance fees and property taxes (BILD. 2010). Larger units also affect the developers bottom line. They tend to be less profitable then one bedroom units.

Findings from a recent report from the Ryerson City Building Institute (2017) indicated that the average price of a three-bedroom condominium unit is $\$ 900,000$. This cost is only marginally lower than the price of an existing ground-related housing option in the City of Toronto. This raises the question of whether these units will be affordable for future households with children, and whether these households would prefer the idea of living in a vertical community over a ground related suburban home. Findings from a BILD report argue that the price differential on these types of choices is not large enough to sway people towards purchasing a condominium (BILD, 2010). A critical challenge identified in the Growing Up Study is affordability. Staff have acknowledged that providing larger units will result in higher housing prices for those unit types. However, these guidelines work largely to assist in the provision of more housing stock for larger households, since there are currently limited housing opportunities and choices in the market. However, there are no financial incentives, such as development charge reductions, to further encourage this type of growth in new developments.

This finding is particularly concerning in the wake of the City's latest development charge by-law review which proposes to increase development charges for 2 bedroom apartments by 104 per cent. This would effectively increase the development charge for larger units from $\$ 25,366$ per unit to $\$ 51,740$ per unit (City of Toronto, 2018). This poses a significant challenge to maintaining the affordability of these units. Perhaps more notably, this rate increase comes following a five-year planning process to encourage the development of larger family units. This increase can lead to the cross-subsidization of funds, as Blais (2009) pointed out in her research on suburban growth patterns. This can potentially occur with regard to the 
development charges on smaller and larger units. BILD members have pointed out that requiring larger units in new developments are likely to transfer costs from large units onto the buyers of smaller units (BILD, 2010). A higher development charge will ultimately increase the extent to which this occurs. 


\section{Chapter 5: Discussion and Recommendations}

Toronto faces several growth challenges including changing demographics, affordable housing, deteriorating infrastructure and increased expenditure demands. Amongst these challenges, revenue sources to finance these demands have remained largely the same, limited to property taxes, user fees and transfers from federal and provincial governments (Kitchen and Slack, 2016). Due to these factors, municipalities are often forced to increase development charges to the greatest extent possible in an attempt to close the fiscal gap. Development charge increases typically come from chief administrative officers and finance departments and are generally supported by municipal politicians for their low political cost in comparison to raising property taxes (Amborski, 2011). This paper argues that as a result, Toronto's fiscal policy works counterintuitive to urban planning policy, linked to achieving affordable housing solutions and desirable development outcomes. Municipalities will need to increasingly consider the impact of these charges and weigh them against the potential alternatives to finance growth related expenditures.

The next section will summarize the potential alternative approaches to finance growth related expenditures which have the potential to better align with planning policy objectives identified in the City of Toronto Official Plan.

\section{Recommendation 1: Expand the Affordable Housing Definition in the Open Door Program}

The Open Door Program considers the impact of development charges on the financial viability of affordable housing development projects. This program is necessary to encourage the construction of new affordable units within Toronto. The current type of housing eligible under this program only includes affordable rental housing. Affordable rental housing by definition 
within the program guidelines is housing where "the total monthly shelter cost is below $80 \%$ average market rent (AMR)" (City of Toronto, 2017). Experts have suggested that creating this type of affordable housing stock does not meet the needs of most residents of Toronto and must be re-examined to contribute to a wider range of housing options (Pagliaro \& Mathieu, 2017).

The City of Toronto should consider expanding the scope of the Open Door Program to include a wider variety of development projects that can contribute to increasing affordable housing stock. This would include expanding the eligibility requirement to include not-for-profit housing providers operating under and affordable homeownership models. Additionally the city should consider how other forms of tenure can fit into the Open Door requirements, including purpose built rental units. Currently, these housing developers pay the full development charge rate, despite their contributions to building more housing types. Having financial incentives such as development charge exemptions may encourage these types of developments and help to achieve Official Plan policy objectives surrounding housing.

\section{Recommendation 2: Reduce Development Charges in Light of Enhanced Transfers for Public Transit from Upper Levels of Government}

A large portion of development charge revenues are allocated towards funding public transit in Toronto. This includes 37 per cent of the residential development charge attributed to transit and 44 per cent of the non-residential charge (City of Toronto, 2018). This has become problematic for several reasons. One major impact is that it contributes to higher housing prices and issues surrounding equity related to who pays and who benefits. The latest proposed increase to the City of Toronto development charge by-law intends to further use these funds to finance new transit projects. 
Recently, the federal Infrastructure Minister of Canada announced a significant amount of funding for Toronto's transit plans. This includes $\$ 9$ billion in funding from both the Federal and Provincial government dedicated to funding Toronto (Spurr, 2018). The Federal Government announced Toronto will receive more than half of the allocated $\$ 8.34$ billion in federal funding projects between now and 2028, with Toronto receiving $\$ 4.89$ billion. The Province has agreed to match this funding with $\$ 4.04$ billion (Spurr, 2018). This investment from both levels of government will significantly bring the City closer to pay for its long wish list of prioritized projects, such as the Scarborough subway extensions, John Tory's Smart Track, the Downtown relief line, and waterfront LRT. Toronto is likely to have to match some of this funding as the deferral government will typically fund up to 40 per cent of the cost of the project, and the province covering 33 per cent (Spurr, 2018).

While Federal and Provincial funding for growth related infrastructure have decreased in recent years, this announcement is long awaited. Government grants must be deducted as per the Development Charges Act in the fee calculation. Therefore, this type of funding must be associated with lower development charges which can alleviate its impacts on housing affordability.

\section{Recommendation 3: Explore Alternative Transit Funding Opportunities}

Enhanced transfers from upper levels of government is welcome news for Toronto's public transit initiatives; however, this funding does not cover Toronto's long wish list of future transit projects. Additional funding is still required. It can be argued that development charges are not the appropriate tool to finance new transportation infrastructure. This is largely due to equity issues. For example, as a majority of development activity currently occurs in the 
Downtown and Central Waterfront, funds collected by development charges is being used to finance transit infrastructure to the suburbs. This challenge the benefit principle of just taxation, blurring the lines between who pays for service and who benefits. Alternatively, Land Value Capture (LVC) tools have been used to capture the so-called unearned increment of public investment decisions (Amborski, 2011). In practise, this can be a tax used to capture land value increases through a special assessment on the existing property tax. While LVC tools may be effective in areas where there is new public investment in transit infrastructure. This would function so that properties that have benefitted from an increase in land value due to the transit investment, would have a separate tax to assist in the financing of this infrastructure. This model should be explored on future transit expansion projects such as the Scarborough Subway Extension and Downtown Relief Line. This approach may also alleviate the equity issues associated the current structure of development charges. 


\section{Chapter 6: Conclusion}

The remarkable pace at which Toronto continues to grow is an important component of the City's economic wellbeing; however, these pressures have created a new set of challenges to maintain the livability of the City. This significant growth has placed extreme pressure on Toronto's infrastructure and existing services highlighting the current infrastructure gap. Lack of investment in public transit over the past two decades has led to overcrowded subways, high levels of congestions of city streets, and a lack of transportation alternatives. On top of this, Toronto's hot housing market has experienced some of the highest year-over-year price gains on record, contributing to significant housing affordability issues.

The proposed increase to Toronto's Development Charge By-law works counter to the planning goals and policy objectives as outlined in the City of Toronto Official Plan. This paper argued that Toronto should reduce the quantum of development charges in order to support planning objectives and seek alternative financing tools to fund growth related capital costs. In doing so, it was found that the academic literature reaffirms the potential negative impacts of high development charges related to housing affordability and desirable growth outcomes. The recommendations outlined in this paper summarized alternative approaches to financing growth related capital costs that would help to alleviate the development charge burden placed on new developments. An overreliance on development charges is problematic from a planning perspective and the city of Toronto should be cautious as to who bears the burden of the charge. 


\section{References}

Altus Group. (2013). Government Charges and Fees on New Homes in the Greater Toronto Area. Retrieved from: http://www.bildgta.ca/Assets/Bild/UPLOADEDFILES/Government_Relations/Publicatio n s/REVISED\%20Government\%20Charges\%20in\%20the\%20GTA\%20\%20July\%2023.pdf

Altus Group. (2009). The Time is Right - Alternatives to Development Charges. Retrieved from: http://www.bildgta.ca/Assets/Bild/UPLOADEDFILES/Government_Relations/Reports/T h e \%20Time\%20Is\%20Right\%20Final\%20Report.pdf

Altus Group. (2011). The Urban Infrastructure Challenge in Canada: Making Use of Municipal Debt Options. Retrieved from: https://suma.org/img/uploads/documents/Altus\%20Group\%20Report\%20for\%20CHBA $\% 20$ on\%20infrastructure\%20challenges.pdf

Amborski, D \& Clayton, F. (2016). Countering Myths about Rising Ground-Related Housing Prices in the GTA: New Supply Really Matters. Centre for Urban Research \& Land Development. Retrieved from: https://www.ryerson.ca/content/dam/cur/pdfs/policycommentaries/Countering $\% 20 \mathrm{My}$ ths \%20about\%20Rising\%20GroundRelated\%20Housing\%20Prices\%20in\%20the \%20GT \%20\%20New\%20Supply\%20Really\%20Matters CUR\%20Policy\%20Report 2017.045p df

Amborski, D. (1988). Impact Fees Canadian Style: The use of development charge in Ontario. Development Impact Fees: Policy Rationale Practise, Theory and Issues, edited by A.C. Nelson. 52-86. Chicago: Planners Press

Amborski, D. (2011). Alternatives to Development Charges for Growth Related Capital Costs. Prepared for the Ontario Ministry of Municipal Affairs and Housing. Retrieved from: http://www.rccao.com/news/files/RCCAO_March2011_REPORT-1.pdf

Building Industry and Land Development Association. (2008). Over the Top: The Impact of Development Charges on New Homebuyers. Retrieved from: http://www.bildgta.ca/Assets/Bild/UPLOADEDFILES/Government_Relations/Reports/C _REPORT_08_FINAL.pdf

Building Industry and Land Development Association. (2014). Review of the Development Charges System in Ontario. Retrieved from: http://www.bildgta.ca/Assets/Bild/UPLOADEDFILES/Government_Relations/Publicatin s/DC\%20Consultation\%20Submission\%20Jan\%202014\%20(2).pdf

Building Industry and Land Development Association (2010). BILD Report: City of Toronto Official Plan Amendment to Encourage the Development of Units for Households with Children. Retrieved from: 
Burge, G, Trosper, T, Nelson, A, Juergensmeyer, J \& Nicholas, C. (2013). Can Development Impact Fees Help Mitigate Urban Sprawl? Journal of the American Planning Association. (79) 3: 235-248.

Burge, G \& Ihlanfeldt, K. (2009). Development Impact Fees and Employment. Regional Science and Urban Economics. (39). 54-62.

Burge, G \& Ihlanfeldt, K. 2006. Impact Fees and Single Family Home Construction. Journal of Urban Economics. (60) 2: 284-306.

Blais, P. (2010). Perverse Cities: Hidden Subsidies, Wonky Policies and Urban Sprawl. UBC Press, Vancouver

Bryant, L. (2017). Housing Affordability in Australia: An Empirical Study of the Impact of infrastructure Charges. Journal of Housing and the Built Environment. 32: 559-579.

C.N. Watson and Associates (n.d). Development Charges Impact Policy Paper. Prepared for the City of Hamilton. Retrieved from: http://www2.hamilton.ca/NR/rdonlyres/A5BD00300BFF-4DF2-B61A-D7038F11FC4C/0/Jun17Item88idcimpactpolicy.pdf

Canadian Urban Institute. (2009). Mid Rise Symposium 2009. Breaking Barriers, Building Confidence: Making Mid Rise Work In Ontario

Canadian Centre for Economic Analysis. (2017). Understanding the forces driving the shelter affordability issue: A linked path assessment of housing market dynamics in Ontario and the GTHA. Retrieved from: https://www.cancea.ca/sites/economicanalysis.ca/files/Affordability\%20Phase\%202\%20-\%20final\%20report.pdf

City of Hamilton. (n.d.) Policy Paper. http://www2.hamilton.ca/NR/rdonlyres/A5BD0030-0BFF 4DF2-B61A-D7038F11FC4C/0/Jun17Item88idcimpactpolicy.pdf

City of Toronto. (2017). Open Door Affordable Housing Guidelines. Retrieved from: https:/www.toronto.ca/wp-content/uploads/2017/10/96ee-OpenDoorGuidelines- F.pdf

City of Toronto. (2017). Growing Up: Planning for Children in New Vertical Communities. Report for Action. Retrieved from: https://www.toronto.ca/legdocs/mmis/2017/pg/bgrd/backgroundfile-103919.pdf

Dalglish, B. (January 20, 2014). "Mid-rise Buildings Challenge Toronto Developers, City" The Globe and Mail.

Galloway, M. (2018). Metro Morning. Toronto: CBC. Retrieved from, http://www.cbc.ca/listen/shows/metro-morning/segment/15495999

Habitat for Humanity Greater Toronto Area (n.d.). Retrieved from, 
https:/habitatgta.ca/

Hemson Consulting. (2018). City of Toronto: 2018 Development Charges Background Study. Retrieved from: https://www.toronto.ca/legdocs/mmis/2018/ex/bgrd/backgroundfile110943.pdf

Ihlanfeldt, K \& Shaugnessy, T. 2004. An Empirical Investigation of the effects of impact fees on housing and land markets. Regional Science and Urban Economics (34) 639-661.

Jones, A. (2015). Impact Fees and Employment Growth. Economic Development Quarterly. (29) 4: 341-346.

Nelson, C, Bowles, L., Juergensmeyer, J, \& Nicholas, J. (2008). A Guide to Impact Fees and Housing Affordability.

Pagliaro, J. and E. Mathieu (October 2, 2017). "As mayor celebrates program, critics say that definition of affordable housing needs review". The Toronto Star.

Slack, E. 2002. Municipal Finance and the Pattern of Urban Growth.C.D. Howe Institute. Retrieved from: http://citeseerx.ist.psu.edu/viewdoc/download?doi=10.1.1.368.9285\&rep=rep1\&type= pdf

Slack, E. \& Bird, R. 1991. Financing Urban Growth through Development Charges. Canadian Tax Journal (39) 5: 1288-1304.

Slack, E. 1994. Development Charges in Canadian Municipalities: An Analysis. Intergovernmental Committee on Urban and Regional Research.

Shishir, M. 2013. Do All Impact Fees Affect Housing Prices the Same? Journal of planning Education and Research. (33) 4: 442-455.

Shishir, M. 2007. Do Impact Fees Raise the Price of Existing Housing? Housing Policy Debate. (18) 4 .

Spurr, B. (March 14, 2018). "Toronto transit plans get major boost from federal, provincial governments". The Toronto Star.

Statistics Canada. (2017). Housing in Canada: Key Results from the 2016 Census. Retrieved from: http://www.statcan.gc.ca/daily-quotidien/171025/dq171025c-eng.pdf

Tomaly, R \& Skaburskis, A. 2003. Development Charges and City Planning Objectives: The Ontario Disconnect. Canadian Journal of Urban Research (12) 1: 142- 161.

Tomaly, R \& Skaburskis, A. 1997. Negotiating Development Charges in Ontario: Average Cost versus Marginal Cost Pricing of Services. Urban Studies. (34) 12. 1987-2002. 
Wilkes, D. (January 27, 2018). "New neighbourhoods paying more than fair share of fees". The Toronto Star.

Yinger, J. (1998). The Incidence of Development Fees and Special Assessments. National Tax Journal. 51-1. 


\section{Appendices}

Appendix A: Residential Development Charge Rate, City of Toronto 2018

Below is a chart that shows the eligible services calculated as part of its 2018 development charge by-law.

22

City of Toronto By-law -2018

\section{SCHEDULE A TO CH. 415 ART. 1 \\ RESIDENTIAL DEVELOPMENT CHARGE RATES}

EFFECTIVE 2018

\begin{tabular}{|l|r|r|r|r|r|r|}
\hline & \multicolumn{6}{|c|}{ Residential Charge By Unit Type } \\
\cline { 2 - 7 } Service & $\begin{array}{c}\text { Singles \& } \\
\text { Semis }\end{array}$ & $\begin{array}{c}\text { Multiples 2+ } \\
\text { Bedrooms }\end{array}$ & $\begin{array}{c}\text { Multiples 1 } \\
\text { Bed and } \\
\text { Bach. }\end{array}$ & $\begin{array}{c}\text { Apartments } \\
\text { 2+ Bedrooms }\end{array}$ & $\begin{array}{c}\text { Apartments } \\
\text { 1 Bed and } \\
\text { Bach. }\end{array}$ & $\begin{array}{c}\text { Dwelling } \\
\text { Room }\end{array}$ \\
\hline Spadina Subway Extension & $\$ 2,657$ & $\$ 2,196$ & $\$ 1,102$ & $\$ 1,555$ & $\$ 1,015$ & $\$ 720$ \\
Transit (balance) & $\$ 28,412$ & $\$ 23,484$ & $\$ 11,780$ & $\$ 16,631$ & $\$ 10,857$ & $\$ 7,700$ \\
Parks and Recreation & $\$ 10,314$ & $\$ 8,525$ & $\$ 4,277$ & $\$ 6,038$ & $\$ 3,941$ & $\$ 2,795$ \\
Library & $\$ 1,810$ & $\$ 1,496$ & $\$ 751$ & $\$ 1,060$ & $\$ 692$ & $\$ 491$ \\
Subsidized Housing & $\$ 6,917$ & $\$ 5,717$ & $\$ 2,868$ & $\$ 4,049$ & $\$ 2,643$ & $\$ 1,875$ \\
Shelter & $\$ 910$ & $\$ 752$ & $\$ 377$ & $\$ 533$ & $\$ 348$ & $\$ 247$ \\
Police & $\$ 1,073$ & $\$ 887$ & $\$ 445$ & $\$ 628$ & $\$ 410$ & $\$ 291$ \\
Fire & $\$ 445$ & $\$ 367$ & $\$ 184$ & $\$ 260$ & $\$ 170$ & $\$ 120$ \\
Paramedic Services & $\$ 498$ & $\$ 412$ & $\$ 207$ & $\$ 292$ & $\$ 190$ & $\$ 135$ \\
Development-related Studies & $\$ 508$ & $\$ 420$ & $\$ 211$ & $\$ 297$ & $\$ 194$ & $\$ 138$ \\
Civic Improvements & $\$ 243$ & $\$ 201$ & $\$ 101$ & $\$ 142$ & $\$ 63$ \\
Child Care & $\$ 763$ & $\$ 630$ & $\$ 316$ & $\$ 446$ & $\$ 291$ & $\$ 33$ \\
Health & $\$ 8$ & $\$ 7$ & $\$ 3$ & $\$ 5$ & $\$ 207$ \\
Pedestrian Infrastructure & $\$ 49$ & $\$ 41$ & $\$ 20$ & $\$ 29$ & $\$ 19$ & $\$ 13$ \\
\hline Subtotal General Services & $\mathbf{\$ 5 4 , 6 0 7}$ & $\mathbf{\$ 4 5 , 1 3 5}$ & $\mathbf{\$ 2 2 , 6 4 2}$ & $\mathbf{\$ 3 1 , 9 6 5}$ & $\mathbf{\$ 2 0 , 8 6 6}$ & $\mathbf{\$ 1 4 , 8 0 0}$ \\
\hline Roads and Related & $\$ 14,965$ & $\$ 12,369$ & $\$ 6,205$ & $\$ 8,760$ & $\$ 5,718$ & $\$ 4,055$ \\
Water & $\$ 7,275$ & $\$ 6,013$ & $\$ 3,016$ & $\$ 4,258$ & $\$ 2,780$ & $\$ 1,971$ \\
Sanitary Sewer & $\$ 7,828$ & $\$ 6,470$ & $\$ 3,246$ & $\$ 4,582$ & $\$ 2,991$ & $\$ 2,121$ \\
Storm Water Management & $\$ 3,716$ & $\$ 3,071$ & $\$ 1,541$ & $\$ 2,175$ & $\$ 1,420$ & $\$ 1,007$ \\
\hline Subtotal Engineered Services & $\mathbf{\$ 3 3 , 7 8 4}$ & $\mathbf{\$ 2 7 , 9 2 3}$ & $\mathbf{\$ 1 4 , 0 0 8}$ & $\mathbf{\$ 1 9 , 7 7 5}$ & $\mathbf{\$ 1 2 , 9 0 9}$ & $\mathbf{\$ 9 , 1 5 4}$ \\
\hline Total Charge Per Unit & $\mathbf{\$ 8 8 , 3 9 1}$ & $\mathbf{\$ 7 3 , 0 5 8}$ & $\mathbf{\$ 3 6 , 6 5 0}$ & $\mathbf{\$ 5 1 , 7 4 0}$ & $\mathbf{\$ 3 3 , 7 7 5}$ & $\mathbf{\$ 2 3 , 9 5 4}$ \\
\hline
\end{tabular}

NOTE: $\quad$ The development charges described above shall be adjusted pursuant to $\S 415-11$ of this by-law. 
